\title{
Foreword
}

\section{"Imagining children constitutionally: 20 years of strategic litigation and advocacy"}

\section{Karabo Ozah ${ }^{1}$}

Director: Centre for Child Law, Faculty of Law

University of Pretoria

In December 2018, the Centre for Child Law hosted a conference under the theme "Imagining children constitutionally: 20 years of strategic litigation and advocacy". The conference deliberations focused on the following themes:

\begin{tabular}{|l|l|}
\hline $\begin{array}{l}\text { Constitutionalisation of children's } \\
\text { rights }\end{array}$ & Children's rights: An African agenda \\
\hline Child justice \& sexual offences & $\begin{array}{l}\text { Jurisprudence arising from children's } \\
\text { rights instruments }\end{array}$ \\
\hline Corporal punishment & Children and migration \\
\hline
\end{tabular}

The aim of the conference was to celebrate the Centre's contribution to the development of child law and the implementation of children's rights in South Africa over the past 20 years (1998-2018). I wish to thank all the presenters and participants at the conference, who engaged in two and half days of vibrant discussions on imagining children "constitutionally". Special thanks go to the two Constitutional Court Justices who graced our convening - Justice Sisi Khampepe and Justice Albie Sachs. Justice Khampepe delivered a keynote address on day one and Justice Sachs delivered the second keynote address on day two of the conference. I also wish to thank Prof Benyam Mezmur (UWC Prof; ACERWC member $\&$ CRC member) for giving the opening address. Special mention also goes to Adv Steven Budlender SC who argued some of the Centre's landmark cases over the past ten years.

1 I wish to also thank our donors ELMA Foundation and Constitutionalism Fund for their generous financial assistance for the conference as well as the journal special issue. While many worked to ensure the success of the conference, I would like to especially thank the Centre's former director Prof Ann Skelton, Pontso Phahlane, Isabel Magaya, Zita Hansungule and the rest of the Centre for Child Law team for their tireless efforts. Special thanks also go to Isabel Magaya for her assistance with the internal review process for the special issue. Lastly, I would like to thank the University of Pretoria's Faculty of Law and Prof Andre Boraine (the then Dean), for all the support. 
Participants at the conference deliberated not only on South Africa's watershed moments in child rights litigation during this period but also on best practices and developments from other regions. The conference was enriched by presentations from national, regional and international speakers (both academics and legal practitioners). Speakers also included former child clients who shared their experiences on the value of having a legal representative who acted in their interests.

Following the above, I introduce articles and speeches that pursue these and other issues in greater depth. 